\title{
Ethnic Differences in Genetic Immunity to Cancer
}

\author{
Rumyantsev SN* \\ Department of Evolutionary Immunology, USA \\ *Corresponding author: Rumyantsev SN, Department of Evolutionary Immunology, USA
}

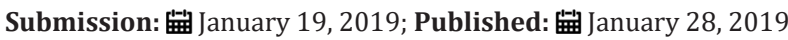

\begin{abstract}
Main goal of this article is to present more exhaustive information about genetic immunity to cancerous disease. The data about the subsistence of the disease in 125 ethnoses around the World have been analyzed. The groups of most immune and most susceptible ethnoses have been revealed. Causative agent of this disease is a specific eukaryotic genomic parasite, spreading amongst humans via its intrusion in the genomes of susceptible organisms. The Intrusion of cancerous genes is performing by contaminated human gametes, either by the sperm or by the egg. The parasite subsistence of human cancerous disease is functioning at the expense of substances and functions derived from the body of its prey. This trait is cruial for the progression of cancerous disease within a human body but intensive nutrition of developed cancerous tissues leads contaminated person to the loss of his body weight. The subsistence is provided with the possession by cancerous subjects of genetic immunity to the victim's immune defense and cell regulation. These new notions provide framework and landmarks for the detection and discovery of genomic roots of cancerous disease and encourage new proposals for its healing and prevention, as well as for the discovery of the origin and evolution of cancerous disease.
\end{abstract}

Keywords: Cancerous disease; Cancerous tissues; Cancerous gametes; Cancerous genealogy; Cell regulation; Embryogenesis; Eukaryotic parasite; Genetic immunity; Genome intrusion; Genomic parasite; Femai cancerous gamete; Healing of cancerous disease; Immune response; Mail cancerous gamete; Parasite invasion of a genome; Ovum; Prevention of cancerous disease; Self-procurement of cancerous disease; Selfish genes; Sexual transmission of cancerous disease; Sperm; Xenogamy

\section{Introduction}

For many decades the ability of cancer to invade human body and subsist in it like a parasite was out of the main stream of the discoveries of the biology, epidemiology, genetics, immunology and pathogenesis of this disease. The ability to withstand the invasion by the means of immunity has been neglected too. The first evidences of genetic immunity against cancer have been received thank to pioneering both families and genealogical observations, that have been made at the beginning of XX Century. Warthin $[1,2]$. Unfortunately, these first evidences have been neglected and forgotten. Most recent data of genetic immunity against cancerous disease are presented. Main goal of this article is to present recent information about genetic immunity to cancer. ethnic differences in susceptibility to cancerous disease. The data about the subsistence of the disease in 125 ethnoses around the World have been analyzed.

\section{Materials and Methods}

Main point has been made on the discovery of ethnic differences in native immunity to cancer. The data base of 1999-2007 Cancer Incidence and Mortality Data 2007 [3]. National Program of Cancer Registries. Betesda, Maryland: USA CDC has been used. The data about the subsistence of the disease in 125 ethnoses around the World have been analyzed.

\section{Results and Discussion}

The differences amongst 125 observed ethnic populations have been analyzed. Two main groups of populations have been revealed: the group of most immune populations and the group of most susceptible populations.

a) Most immune populations (Index of Mortality < 100)

Table 1:

\begin{tabular}{|c|c|c|c|}
\hline \multicolumn{5}{|c|}{ African Populations } \\
\hline Niger & 63.42 & Liberia & 89.21 \\
\hline Benin & 64.3 & Guinea & 90.02 \\
\hline Gambia & 68.24 & Gabon & 90.15 \\
\hline Cape Verde & 74.88 & Sudan & 91.1 \\
\hline Namibia & 82.66 & Togo & 91.14 \\
\hline Guinea Bissau & 83.05 & Ghana & 91.66 \\
\hline Mauritania & 85.66 & Sierra Leone & 92.27 \\
\hline Chad & 88.11 & Central African Republic & 92.86 \\
\hline Congo & 88.18 & Western Sahara & 97.22 \\
\hline Burkina Faso & 88.2 & Cameroon & 97.56 \\
\hline Maldives & 88.93 & Nigeria & 100.13 \\
\hline Cote d Ivoire & 88.96 & Angola & 100.81 \\
\hline & & Senegal & 101.21 \\
\hline
\end{tabular}


Table 2:

\begin{tabular}{|c|c|}
\hline \multicolumn{2}{|c|}{ West Asian Populations } \\
\hline Yemen & 80.36 \\
\hline Oman & 82.05 \\
\hline Saudy Arabia & 91.06 \\
\hline
\end{tabular}

Table 3:

\begin{tabular}{|c|c|}
\hline \multicolumn{2}{|c|}{ Central Asian Populations } \\
\hline Nepal & 85.18 \\
\hline India & 93.96 \\
\hline Shree Lanka & 94.83 \\
\hline Uzbekistan & 99.7 \\
\hline
\end{tabular}

Table 4:

\begin{tabular}{|c|c|}
\hline \multicolumn{2}{|c|}{ Less immune populations } \\
\hline Erithrea & 101.7 \\
\hline Kuwait & 102.12 \\
\hline Ethiopia & 108.03 \\
\hline
\end{tabular}

b) Most susceptible populations

\section{Table 5:}

\begin{tabular}{|c|c|c|c|}
\hline \multicolumn{4}{|c|}{ Populations of West European Origin } \\
\hline Belarus & 218.6 & Slovakia & 276.95 \\
\hline Romania & 224.2 & Italy & 278.61 \\
\hline Poland & 229.59 & Germany & 283.84 \\
\hline Bulgaria & 234.8 & Iceland & 284.35 \\
\hline Portugal & 246.21 & Hungary & 285.39 \\
\hline Lithuania & 251.87 & Lichtenstein & 286.97 \\
\hline Austria & 254.09 & Switzerland & 286.97 \\
\hline Sweden & 269.9 & Czech Republic & 293.83 \\
\hline Italy & 278.1 & Belgium & 321.05 \\
\hline Germany & 283.84 & Norway & 318.29 \\
\hline Switzerland & 286.97 & Ireland & 307.91 \\
\hline Lichtenstein & 286.97 & Netherlands & 304.8 \\
\hline Hungary & 285.39 & France & 303.54 \\
\hline Iceland & 284.35 & Denmark & 338.09 \\
\hline
\end{tabular}

\begin{tabular}{|c|c|c|c|}
\hline England & 292.59 & Portugal & 246.21 \\
\hline Chech Republic & 293.83 & Latvia & 246.77 \\
\hline Estonia & 242.84 & Spain & 249.45 \\
\hline Macedonia & 239.27 & Lithuania & 251.87 \\
\hline Montenegro & 238.25 & Austria & 254.09 \\
\hline Bulgaria & 234.8 & Croatia & 266.86 \\
\hline Poland & 229.59 & Serbia & 269.74 \\
\hline Montenegro & 238.25 & Sweden & 269.99 \\
\hline Macedonia & 239.27 & Estonia & 242.84 \\
\hline $\begin{array}{c}\text { Populations of Native } \\
\text { Australians }\end{array}$ & 397.44 & & \\
\hline \begin{tabular}{c} 
Tasmanian population \\
\hline
\end{tabular} & 49398 & & \\
\hline
\end{tabular}

c) Less susceptible populations

Table 6:

\begin{tabular}{|c|c|c|c|}
\hline Russia & $\mathbf{2 0 4 . 3}$ & Armenia & $\mathbf{2 5 7 . 0 2}$ \\
\hline Turkey & 205.08 & New Zealand & 295.02 \\
\hline Brazil & 205.48 & Canada & 295.72 \\
\hline Argentina & 216.68 & New Caledonia & 297.91 \\
\hline Japan & 217.11 & Korean Republic & 307.77 \\
\hline Kazakhstan & 236.48 & USA & 317.97 \\
\hline & & Current Australians & 322.98 \\
\hline
\end{tabular}

d) South east Asian populations

Table 7:

\begin{tabular}{|c|c|c|c|}
\hline \multicolumn{5}{|c|}{ Melanesian populations } \\
\hline Vanuatu & 107.76 & Thailand & 137.48 \\
\hline Solomon Islands & 116.34 & Indonesia & 133.52 \\
\hline Philippines & 139.98 & Lao PDR & 143.83 \\
\hline Vietnam & 140.41 & & \\
\hline \multicolumn{4}{|c|}{ North African populations } \\
\hline Tunisia & 110.57 & Papua New Guinea & 165.23 \\
\hline Mali & 111.42 & China & 173.97 \\
\hline Morocco & 117.84 & $\begin{array}{c}\text { Korean Dem Re- } \\
\text { public }\end{array}$ & 181.19 \\
\hline Algeria & 123.49 & Libya & 124.12 \\
\hline 11. Egypt & 152.04 & & \\
\hline \multicolumn{4}{|c|}{} \\
\hline
\end{tabular}




\begin{tabular}{|c|c|c|c|}
\hline \multicolumn{4}{|c|}{ South American Populations } \\
\hline Nicaragua & 114.42 & Belize & 160.69 \\
\hline Mexico & 131.54 & Bolivia & 143.39 \\
\hline Honduras & 131.25 & Paraguay & 147.77 \\
\hline Guatemala & 130.39 & Venezuela & 150.03 \\
\hline Panama & 148.44 & Peru & 154.52 \\
\hline Costa Rica & 149.73 & Suriname & 159.64 \\
\hline Dominican Republic & 153.41 & Colombia & 160.63 \\
\hline Guyana & 165.934 & French Guyana & 160.88 \\
\hline Chile & 175.69 & Ecuador & 164.45 \\
\hline \multicolumn{2}{|c|}{ Central Asian Populations } & \multicolumn{2}{|c|}{ Near East Populations } \\
\hline Bangladesh & 104.45 & Azerbaijan & 141.94 \\
\hline Pakistan & 111.82 & $\begin{array}{c}\text { Syrian Arab Re- } \\
\text { public }\end{array}$ & 145.91 \\
\hline Afghanistan & 115.23 & Jordan & 155.4 \\
\hline Iran & 127.69 & Georgia & 181.04 \\
\hline Kyrgyzstan & 137.65 & Greece & 163 \\
\hline
\end{tabular}

The data, that have been presented and analyzed above, are in quied accordance with the theory of invasive origin and parasite subsistence of human cancer [4]. According to data of evolutionary epidemiology, genetic immunity to infectious diseases is elaborated firstly in populations, that had more ancient confrontation with relevant epidemics. Analogous correlations are seen also in the case of genetic immunity to cancer. The above presented data are evidenced, that pandemics of cancerous disease started firstly amongst the populations of West Africa, Abyssinia and India. Most susceptible populations (west Europeans, Australian aborigines and Tasmanians) met the pandemics of cancer far later.

\section{Conclusion}

The differences amongst 125 observed ethnic populations have been analyzed. Two main groups of populations have been revealed: the group of most immune populations and the group of most susceptible populations. These new data have allowed us to conclude that revealed differences are of genetic i.e. of evolutionary origin, compatible to those ones, that have been discovered in the area of genetic immunity against infectious diseases. The above new notions provide framework and landmarks for the detection and discovery of genomic roots of cancer and encourage new proposals for its healing and prevention, as well as for the discovery of the origin and evolution of cancerous disease, as well as of its impact on both ancient and future evolution of humankind $[5,6]$.

\section{References}

1. Warthin AS (1913) Hereditary with reference to carcinoma as shown by the study of the cases examined in the pathological laboratory of the university of michigan, 1895-1913. Archives of Internal Medicine 12(5): 546-555.

2. Warthin AS (1925) The further study of a cancer family. J Cancer Research 9(2): 279-286.

3. Hauser J, Weller CV (1936) A further report on the cancer family of warthin. Am J Cancer 27(3): 434-450.

4. 1999-2007 Cancer Incidence and Mortality Data (2007) National program of cancer registries. Betesda, Maryland, USA CDC.

5. Rumyantsev SN (2018) Parasite subsistence of human cancer. Novel Approaches in Cancer 1(2): 1-15.

6. Rumyantsev SN (2008) Hereditary immunity: fundamental principles and exploitation in life study and health care. Nova Science Publishers, New York, USA, pp. 81-102.

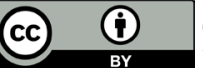

Creative Commons Attribution 4.0 International License

For possible submissions Click Here
Submit Article

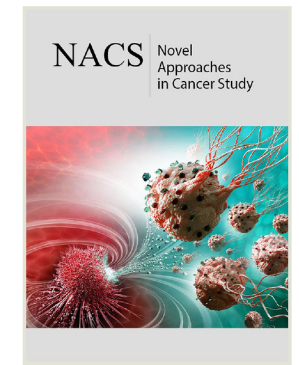

\section{Novel Approaches in Cancer Study \\ Benefits of Publishing with us}

- High-level peer review and editorial services

- Freely accessible online immediately upon publication

- Authors retain the copyright to their work

- Licensing it under a Creative Commons license

- Visibility through different online platforms 